\title{
Pupillary sign of aberrant regeneration of the third nerve
}

回舟

A 55-year-old woman presented with a third nerve palsy and impaired abduction of her right eye. MRI showed a lesion at the orbital apex extending into the cavernous sinus. A biopsy showed invasive Aspergillus fumigatus and she was treated with antifungals with only partial improvement.

Twelve years later, she had complete ptosis, partially restricted abduction, adduction, and depression of the right eye. The right pupil, which did not constrict to light or near vision, constricted on downgaze (video on the Neurology ${ }^{\circledR}$ Web site at Neurology.org), diagnostic of aberrant regeneration, ${ }^{1}$ which occurs when regenerating axons are misdirected to muscles they were not intended, such as the iris sphincter. ${ }^{2}$

Olga R. Rosenvald, $M D$, Simmons Lessell, $M D$

From the Division of Neuro-ophthalmology, Massachusetts Eye and Ear Infirmary, Harvard Medical School, Boston.

Author contributions: Dr. Rosenvald provided patient care, wrote the manuscript draft, and edited the video. Dr. Lessell provided patient care, edited the manuscript, and supervised the video recording and edition.

Study funding: No targeted funding reported.

Disclosure: The authors report no disclosures relevant to the manuscript. Go to Neurology.org for full disclosures.

Correspondence to Dr. Rosenvald: olga.rosenvald@gmail.com

Supplemental data at Neurology.org
1. Czarnecki JS, Thompson HS. The iris sphincter in aberrant regeneration of the third nerve. Arch Ophthalmol 1978;96: 1606-1610.

2. Sibony PA, Lessell S, Gittinger JW Jr. Acquired oculomotor synkinesis. Surv Ophthalmol 1984;28:382-390.

\section{Visit the Neurology ${ }^{\circledR}$ Web Site at Neurology.org}

- Enhanced navigation format

- Increased search capability

- Highlighted articles

- Detailed podcast descriptions

- RSS Feeds of current issue and podcasts

- Personal folders for articles and searches

- Mobile device download link

- AAN Web page links

- Links to Neurology Now ${ }^{\circledR}$, Neurology Today ${ }^{\circledR}$, and Continuum ${ }^{\circledR}$

- Resident \& Fellow subsite

In Find Neurology ${ }^{\circledR}$ on Facebook: http://tinyurl.com/neurologyfan

twitter Follow Neurology ${ }^{\circledR}$ on Twitter: https://twitter.com/GreenJournal 


\section{Neurology}

\section{Pupillary sign of aberrant regeneration of the third nerve \\ Olga R. Rosenvald and Simmons Lessell \\ Neurology 2016;86;1746 \\ DOI 10.1212/WNL.0000000000002642}

This information is current as of May 2, 2016

\section{Updated Information \& Services}

Supplementary Material

\section{References}

Subspecialty Collections

Permissions \& Licensing

Reprints including high resolution figures, can be found at: http://n.neurology.org/content/86/18/1746.full

Supplementary material can be found at: http://n.neurology.org/content/suppl/2016/04/30/WNL.0000000000002 642.DC1

This article cites 2 articles, 0 of which you can access for free at: http://n.neurology.org/content/86/18/1746.full\#ref-list-1

This article, along with others on similar topics, appears in the following collection(s):

All Neuro-ophthalmology

http://n.neurology.org/cgi/collection/all_neuroophthalmology

Fungal infections

http://n.neurology.org/cgi/collection/fungal_infections

Ocular motility

http://n.neurology.org/cgi/collection/ocular_motility

Orbit

http://n.neurology.org/cgi/collection/orbit

Pupils

http://n.neurology.org/cgi/collection/pupils

Information about reproducing this article in parts (figures,tables) or in its entirety can be found online at:

http://www.neurology.org/about/about_the_journal\#permissions

Information about ordering reprints can be found online:

http://n.neurology.org/subscribers/advertise

Neurology ${ }^{\circledR}$ is the official journal of the American Academy of Neurology. Published continuously since 1951, it is now a weekly with 48 issues per year. Copyright @ 2016 American Academy of Neurology. All rights reserved. Print ISSN: 0028-3878. Online ISSN: 1526-632X.

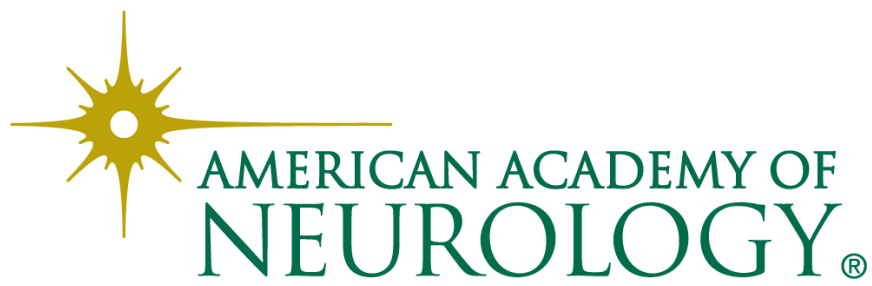

